\title{
TANGGUNG JAWAB ORANG TUA KEPADA ANAK DI ERA DIGITAL PERSPEKTIF HUKUM KELUARGA ISLAM DI INDONESIA
}

\author{
Nur Ahmad Yasin \\ Jl. Panglima Sudirman No. 136 Medaeng waru Sidoarjo. E-Mail: \\ yasin.assidoarji@gmail.com
}

\begin{abstract}
The digital age is an era where technology and information can be accessed by anyone, anywhere and under any conditions, so that it can have a positive and negative impact on parents' responsibilities to children and child development. This article is the result of a bibliographical study on parents' responsibilities to children in the digital age under the perspective of Islamic family law in Indonesia. Data are collected using documentation techniques and analyzed using descriptive methods with deductive mindset. Based on this study, parents are responsible for being more selective in nurturing, educating, and protecting children in today's digital era. They are also asked to understand information technology and systems. Parents must be able to actualize children's rights, including: maintenance of honor (hifZ al-ind), maintenance of religious rights (hifZ al-din), maintenance of the soul (hifz al-nafs), maintenance of reason (hifZ al-'aql) and maintenance of property (hifż al-mäl).
\end{abstract}

Keywords: Responsibility, parents, and the digital era

Abstrak: Era digital merupakan era di mana teknologi dan informasi dapat diakses oleh siapapun, dimanapun dan dalam kondisi apapun, sehingga dapat berdampak positif dan negatif terhadap tanggung jawab orang tua kepada anak dan perkembangan anak. Artikel ini merupakan hasil penelitian pustaka tentang tanggung jawab orang tua kepada anak di era digital perspektif hukum keluarga Islam di Indonesia. Data dihimpun dengan menggunakan teknik dokumentasi dan dianalisis menggunakan metode deskriptif dengan pola pikir deduktif. Berdasarkan penelitian ini, orang tua bertanggung jawab untuk lebih selektif dalam mengasuh, memelihara, mendidik, dan melindungi anak di era digital saat ini. Mereka juga ditutut memahami teknologi dan sistem informasi. Orang tua harus dapat mengaktualisasikan hak-hak anak, diantaranya: pemeliharaan atas kehormatan (hifz al-ird), pemeliharaan atas hak beragama (hifz al-din), pemeliharaan atas jiwa (hiftz al-nafs), pemeliharaan atas akal (hifz al-'aq) dan pemeliharaan atas harta (hifz al-māt).

Kata kunci: tanggung jawab, orang tua, anak, dan era digital

\section{Pendahuluan}


Islam menaruh perhatian besar pada institusi keluarga. Hal ini dapat dibuktikan dengan melihat kenyataan, bahwa hukum Islam tentang keluarga begitu terperinci, mulai dari memilih pasangan hidup, adab berumah tangga dan tanggung jawab dalam menjalin hubungan suami istri, mengasuh anak, kematian serta pembagian harta pusaka dan lain-lain.

Pemeliharaan anak dalam bahasa Arab disebut dengan istilah hadanah. Hadanah yaitu melakukan pemeliharaan anak-anak yang masih kecil, baik laki-laki maupun perempuan, atau yang sudah besar tetapi belum mumayiz, menyediakan sesuatu yang menjadikan kebaikannya, menjaganya dari sesuatu yang menyakiti dan merusaknya, mendidik jasmani, rohani dan akalnya, agar mampu berdiri sendiri menghadapi hidup dan memiliki tanggung jawab.1

Hadhanah berbeda maksudnya dengan pendidikan (tarbiyah). Dalam hadanah disamping terkandung pengertian pemeliharaan jasmani dan rohani, terkandung pula pengertian pendidikan terhadap anak. Pendidik mungkin terdiri dari keluarga si anak dan mungkin juga bukan dari keluarga si anak dan ia merupakan pekerja professional, sedangkan hadanah dilaksanakan dan dilakukan oleh keluarga si anak. Hadanah merupakan hak hadin sedangkan pendidikan belum tentu merupakan hak dari pendidik.2

Anak adalah seorang yang belum berusia 18 (delapan belas) tahun, termasuk yang masih dalam kandungan.3 Sedangkan menurut KHI, anak adalah orang yang belum genap 21 (dua puluh satu) tahun dan belum pernah menikah dan karenanya belum mampu untuk berdiri sendiri.4

Orang tua berkewajiban dan bertanggung jawab sepenuhnya terhadap anaknya sebagaimana amanah dalam undang-undang pasal 26 ayat 1 huruf (a) UU No. 35 Tahun 2014 perubahan atas UU No.

1 Departemen Pendidikan Nasional, Kamus Besar Bahasa Indonesia, edisi 3 (Jakarta: Balai Pustaka: 2007), 380. Lihat juga Abdul Rahman Ghozali, Fiqh Munakahat (Jakarta: Kencana, 2008), 176.

2 Abdul Rahman Ghozali, Fiqh Munakahat, (Jakarta: Kencana, 2008), 176.

3 Undang-Undang No. 35 tahun 2014 perubahan atas Undang-Undang No. 23 tahun 2002 tentang Perlindungan Anak, pasal 1 ayat 1.

4 Abdurrahman, Kompilasi Hukum Islam Di Indonesia (Jakarta: Akademika Pressindo, 2007), 151. 
23 Tahun 2002 Tentang Perlindungan Anak: "Orang tua berkewajiban dan bertanggung jawab untuk: mengasuh, memelihara, mendidik, dan melindungi Anak."5, hal ini juga sesuai dengan perintah Allah dalam surah an Nisa' ayat $9: 6$

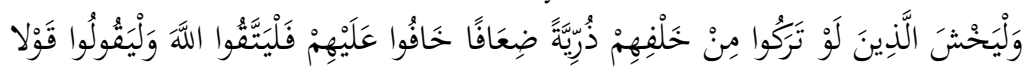

$$
\text { سَدِيدًا }
$$

Dan bendaklah takut kepada Allah orang-orang yang seandainya meninggalkan di belakang mereka anak-anak yang lemah, yang mereka khawatir terbadap (kesejabteraan) mereka. Oleh sebab itu hendaklah mereka bertakwa kepada Allah dan hendaklah mereka mengucapkan perkataan yang benar."

Peranan keluarga, terutama yang diperankan oleh orang tua, merupakan pendidik utama dan pertama bagi manusia, dan keluarga merupakan lingkungan pertama yang dialami oleh anak dalam berinteraksi serta disinilah anak mendapatkan nilai-nilai dan kebiasaan-kebiasaan di dalamnya.7 Oleh sebab itu, orang tua mempunyai tanggung jawab untuk memberikan nilai-nilai dan kebiasaan-kebiasaan baik yang sesuai dengan ajaran-ajaran agama Islam.

Di era digital ini perkembangan teknologi semakin pesat sesuai dengan perkembangan zaman. Alat-alat teknologi bukan menjadi alat-alat yang langka untuk ditemukan. Hampir semua aktifitas yang berhubungan dengan pendidikan, sosial-budaya, olahraga, ekonomi maupun politik selalu memanfaatkan kecanggihan teknologi untuk mencari informasi dan membantu melaksanakan setiap kegiatankegiatannya dalam pemecahan suatu masalah.

Pengguna teknologi yang sering kita jumpai sekarang ini adalah anak-anak. Mereka tampak asik dengan teknologi canggih yang ada di tangan. Anak-anak biasa mendapatkan teknologi canggih dari kedua orangtuanya. Kedua orangtua sengaja memberikan teknologi

5 UU Perlindungan Anak..., pasal 26 Ayat 1 Huruf (a).

6 Departemen Agama. Al-Qur'an dan Terjemahnya, (Bandung: CV. Penerbit J-ART, 2006), 78.

7 Muchsin, Menggagas Etika dan Moral di Tengah Modernitas (Surabaya: CV. Adis, 2002), 25 . 
canggih kepada anaknya untuk kemudahan komunikasi. Namun anak-anak terkadang salah menggunakan teknologi.

Anak-anak lebih cepat dalam menguasai gadget daripada orangtuanya. Namun, penggunaan gadget di kalangan anak-anak sering berdampak negatif. Karena anak-anak lebih cepat beradaptasi dengan teknologi yang ada sehingga anak-anak sering terlena dengan kecanggihan teknologi. Anak-anak yang sering menggunakan teknologi, seringkali lupa dengan lingkungan sekitarnya. Mereka lebih memilih berhadapan dengan teknologi canggih yang mereka punya dibandingkan dengan bermain bersama teman-teman di taman bermain atau di lingkungan sekitar tempat tinggalnya.

Penelitian yang berjudul Keamanan Penggunaan Media Digital pada Anak dan Remaja di Indonesia yang dilakukan oleh lembaga PBB untuk anak-anak, UNICEF bersama para mitra termasuk Kementerian Komunikasi dan Informatika dan Universitas Harvard Amerika Serikat, mencatat pengguna internet di Indonesia yang berasal dari kalangan anak-anak dan remaja diprediksi mencapai 30 juta. Penelitian ini juga mencatat adanya kesenjangan digital yang kuat antara anak dan remaja yang tinggal di perkotaan dengan yang tinggal di pedesaan. Data tersebut merupakan hasil penelitian studi dengan menelusuri aktivitas online dari sampel anak dan remaja yang melibatkan 400 responden berusia 10 sampai 19 tahun di seluruh Indonesia dan mewakili wilayah perkotaan dan pedesaan. Sebanyak 98 persen dari anak dan remaja mengaku tahu tentang internet dan 79,5 persen di antaranya adalah pengguna internet. Dalam penelitian ini, ada sekitar 20 persen responden yang tidak menggunakan internet. 8

Penggunaan gadget terhadap anak yang begitu banyak dan diselingi dengan orang tua yang kuarang aktif mengawasi anak serta memberikan pendidikan yang sesuai dengan ajaran Islam, sehingga hal ini membawa dampak pada Gangguan perkembangan psikologis termasuk sifat agresif, asosial, dan sulit fokus pada anak, dikarenakan minimnya interaksi sosial karena anak cenderung lebih asyik bermain dengan gadget. Sedangkan, keterlambatan tumbuh

8 Aditya panji, "Hasil Survei Pemakaian Internet Remaja Indonesia", https://tekno.kompas.com/read/2014/02/19/1623250/Hasil.Survei.Pemakaia n.Internet.Remaja.Indonesia, " 28 maret 2018”. 
kembang meliputi delay speech serta gangguan pertumbuhan fisik yang disebabkan oleh kurangnya aktivitas fisik.

Anak-anak yang terlalu sering menggunakan gadget sejak dini terutama untuk bermain game, juga cenderung memiliki kepribadian yang rapuh berupa tidak mandiri, cengeng, daya juang rendah, sulit menyelesaikan masalah, dan bersikap instan. Permainan di dalam gadget yang selalu menyediakan pilihan instan untuk menyelesaikan masalah menyebabkan anak-anak memiliki pribadi yang demikian. Sedang ketika menghadapi masalah di kehidupan nyata, anak sering dihadapkan pada berbagai pilihan yang tidak mudah dan harus menghadapi orang lain dengan berbagai karakter dan kepentingan. 9

Dampak negatif, selain pada psikologis dan tumbuh kembang anak, Menurut Yohana berdasar pantauan kementeriannya bersama lembaga pemantau dan analisis media daring, Katapedia, pada periode September-November 2016 saja, tercatat ada 1.200 cuitan di twitter mengenai pronografi anak. Data ini yang tercacat, bagaimana dengan yang tidak tercatat? Kemungkinan lebih banyak lagi. Sedangkan menurut data dari Komisioner Bidang Pornografi dan Cybercrime Komisi Perlindungan Anak Indonesia ( KPAI) Margaret Aliyatul Maimunah mengatakan, sepanjang 2017 tercatat sebanyak 514 laporan kasus pornografi dan cybercrime yang masuk ke KPAI.10

Berdasarkan uraian di atas, maka peneliti merasa tertarik dan menganggap perlu untuk melakukan penelitian atas wacana tersebut dengan judul Tanggung Jawab Orang Tua kepada Anak di Era Digital Perspektif Hukum Keluarga Islam di Indonesia.

Kajian tentang tanggujawab orang tua terhadap anak memang bukan satu-satunya dan pertama kali dilakukan. Karena dari literatur ilmiah maupun buku-buku yang telah peneliti telaah, ada beberapa yang membahas masalah yang sama walaupun dalam porsi dan spesifikasi yang beragam. Misalnya penelitian yang berjudul

9 Rita pranawati, "menjadi orang tua di era digital", https://ritapranawati.id/2018/03/20/menjadi-orangtua-di-era-digital/, "28 maret 2018".

10KPAI, "era digital jaman now membuat para ibu harap cemas", http://www.kpai.go.id/berita/era-digital-jaman-now-membuat-para-ibu-harapharap-cemas/ "28 maret 2018". 
Penetapan Hak Hadanah Anak yang Belum Mumayiz. Kepada Ayah (Analisis Putusan Pengadilan Agama Purwokerto Nomor: 0295/Pdt.G/2015/PA.Pwt) yang ditulis oleh Anggun Retno Wardani (2016) dan penelitian yang berjudul Tanggung Jawab Orang Tua Terbadap Kesejabteraan Anak Ditinjau Dari Undang-undang Nomor 4 Tabun 1979 Tentang Kesejabteraan Anake (Studi pada Tunawisma Di Kota Bengkulu) yang ditulis oleh Ardani Mahendra (2014). Selain itu, ada juga penelitian berjudul Analisis Maslabah Terbadap Tanggung Jawab Orang Tua Dalam Perlindungan Anak. Terlantar Dari Hasil Nikah Siri (Studi Kasus di Desal Kelurahan Bongkaran Kecamatan Pabean Cantian Kota Surabaya) yang ditulis oleh Lusi Ratnasari (2017). Dari semua kajian yang ada tentang tanggungjawab orang tua kepada anak, belum ada yang mengaitkannya dengan era digital serta menggunakan perkspektif hukum keluarga Islam. kajian ini bermaksud mengisi kekosongan tersebut.

\section{Tanggung Jawab Orang Tua Kepada Anak Prespektif Hukum Keluarga Islam.}

Dalam Islam terdapat beberapa petunjuk tentang perlindungan terhadap hak-hak anak. Sejumlah ayat Al-Qur'an dan Hadist Nabi SAW secara garis besar mengemukakan hak-hak anak sebagai berikut :

1. Hak anak dalam mendapatkan asuhan dan pemeliharaan.

Setiap anak dilahirkan memerlukan perawatan, pemeliharaan, dan pengasuhan untuk mengantarkannya menuju kedewasaan. Pembentukan jiwa anak sangat dipengaruhi oleh cara perawatan dan pengasuhan anak sejak dia dilahirkan. Tumbuh kembang anak diperlukan perhatian yang serius, terutama masa-masa sensitif anak, misalnya balita (bayi dibawah lima tahun). Pertumbuhan kesehatan mengalami masa-masa rawan penyakit karena ketahan fisiknya masih lemah.11

Demikian pula perkembangan psikologis anak juga mengalami fase-fase yang memiliki karakteristik yang berbedabeda sesuai dengan tingkat perkembangan jiwanya. Lingkungan terutama orang tua memiliki andil yang cukup besar dalam

11 Mufidah, Psikologi Keluarga Islam Berwawasan Gender, (Malang: UIN-Malang Press, 2008), 308. 
menentukan tumbuh kembang anak. Keteladanan langsung dari orang tua baik ayah maupun ibu dalam membentuk kepribadian anak menjadi kata kunci yang harus ditekankan.12

Oleh karena itu hak pengasuhan anak secara ideal adalah oarang tua sendiri, kecuali ada halangan syara' yang mengharuskan pindahnya hak asuh orang tua kepada orang lain yang lebih menjamin tumbuh kebang anak dengan baik.

2. Hak anak dalam kepemilikan harta benda.

Hukum Islam menepatkan anak yang baru dilahirkan telah menerima hak waris. Hak waris maupun harta benda lainnya, tentu belum dapat dikelola oleh anak karena keterbatasan kemampuan untuk melakukannya. Karena itu orang tua terhadap amanat ini dapat mengelola hak atas harta benda anak untuk sementara waktu sampai ia mampu untuk mengelola sendiri. untuk menjaga kemaslahatan dan melindungi hak properti ini13,

3. Hak anak dalam memperoleh pendidikan dan pengajaran.

Semua anak yang terlahir di dunia mendapatkan hak untuk memperoleh pendidikan dan pengajaran. Hak pendidikan ini bagi anak bersifat konprehensif, baik dalam mengembangkan nalar berfikirnya, menentukan sikap dan perilaku yang mulia, memiliki keterampilan untuk kehidupannya, dan menjadikan sebagai manusia yang memiliki kepribadian yang baik.

Pendidikan bagi anak merupakan kebutuhan vital yang harus diberikan dengan cara-cara yang bijak untuk menghantarkannya menuju kedewasaan yang baik. Kesalahan dalam mendidik anak di masa kecil akan mengakibatkan rusaknya generasi yang akan datang.14 Kedua orang tua turut mempengaruhi pembentukan kepribadian anak yang paling besar pengaruhnya terhadap anak. Sebagaimana hadist Nabi SAW dalam Shabih Bukhari no.1296 menegaskan:15

12 Rifa Hidayah, Psikologi Pengasuban Anak, (Malang: UIN-Malang Press, 2009), 40. 13 Mufidah, Psikologi..., 309. 


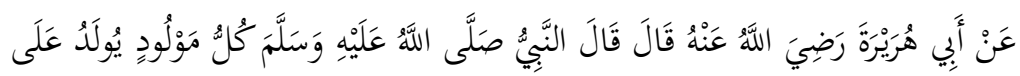

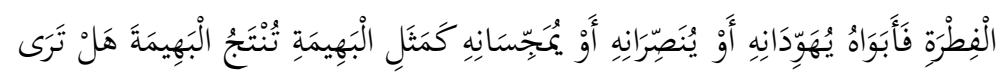 فِيًَا جَذْعَاءَ}

Dari Abu Hurairah radliallahu 'anhu berkata; Nabi Shallallahu'alaihiwasallam bersabda: "Setiap anak dilahirkan dalam keadaan fithrah. Kemudian kedua orang tuanyalah yang akan menjadikan anak itu menjadi Yahudi, Nashrani atau Majusi sebagaimana binatang ternak yang melahirkan binatang ternak dengan sempurna. Apakah kalian melihat ada cacat padanya?".

4. Hak anak untuk mendapatkan perawatan dan perlakuan sosial.

Salah satu perbuatan yang amat dianjurkan dalam Islam adalah menunjukkan kasih sayng dan memelihara anak sebaikbaiknya. Tanggung jawab kedua orang tua merupakan perioritas utama. Sesuai dengan perintah Rosulullah, si bayi harus mulai diberi makanan, nama yang baik, serta rambut kepalanya dicukur, setelah berumur 7 hari. Semua itu dimaksudkan agar anak nantinya tumbuh subur dan sehat.16

Lepas dari semua itu orang tua haruslah dengan senang hati memikul tanggung jawab, memelihara dan membesarkan anak itu. Orang tua tidak sekedar memberi petunjuk dengan kata-kata, tapi juga lewat perbuatan. Kenyataannya, setiap orang tua sholih selalu tercemin juga pada anaknya.

Tanggung jawab serta kasih sayang terhadap anak merupakan masalah yang amat penting dalam agama. Bahkan jika tidak ada satupun keluarga dekat yang mampu merawat anak, tanggung jawab itu harus dipikul bersama-sama oleh masyarakat muslim, baik lembaga pemerintah atau orang biasa.

\section{Tanggung Jawab Orang Tua Kepada Anak Dalam Hukum Positif}

Orang tua adalah pembinaan pribadi yang pertama dalam hidup anak. Menurut Undang-Undang Nomor 4 Tahun 1979 Tentang Kesejahteraan Anak Pasal 9 yang menyatakan bahwa, Orang tua

16 Mahmudah, Keluarga Muslim, (Surabaya: PT. Bina Offset, 1994), 256. 
adalah yang pertama-tama bertanggung jawab atas terwujudnya kesejahteraan anak baik secara rohani, jasmani maupun sosiale.

1. Dalam Undang-undang No. 1 Tahun 1974 tentang Perkawinan

Dalam kenyataannya, anak-anak banyak tidak mengetahui akan hak dan kewajibannya, karena itu perlu mendapatkan bantuan dan perlindungan dalam pelaksanaan hak dan kewajibannya demi terwujudnya kesehjahteraan anak. Sebagaimana telah diatur dalam undang-undang No. 1 tahun 1974 tentang pokok-pokok perkawinan pasal 45 ayat 1, yaitu: "kedua orang tua wajib memelihara dan mendidik anak-anak mereka sebaik-baiknya".17

2. Dalam Kompilasi Hukum Islam (KHI)

Pengertian hadhanah menurut Pasal 1 Huruf g Kompilasi Hukum Islam adalah: "Pemeliharaan anak, yaitu kegiatan mengasuh, memelihara dan mendidik anak hingga dewasa atau mampu berdiri sendiri”. 18

KHI menjelaskan dalam Pasal 77 ayat 3 bahwa suami istri memikul kewajiban untuk mengasuh dan memelihara anak-anak mereka, baik mengenai pertumbuhan jasmani, rohani maupun kecerdasannya dan pendidikan agamanya.

3. Dalam Undang-undang No. 35 tahun 2014 tentang perubahan atas undang-undang No. 23 Tahun 2002 Tentang Perlindungan Anak

Menurut undang-undang No. 35 tahun 2014 tentang perubahan atas undang-undang No. 23 Tahun 2002 Tentang Perlindungan Anak Pasal 1 ayat 4 menyatakan bahwa "Orang Tua adalah ayah dan/atau ibu kandung, atau ayah dan/atau ibu tiri, atau ayah dan/atau ibu angkat".19 Jadi orang tua bisa dikatakan dalam hal ini keluarga merupakan lingkungan kehidupan yang dikenal anak untuk pertama kalinya di dalam berinteraksi maupun berelasi dengan lingkungan sosialnya.

17 Burgerlijk Wetbouk, Kitab Undang-undang Hukum Perdata, Terj. Soesilo dan Pramudji, (Rhedbook Publisher,2008), 470.

18 Ibid., 505.

19 Undang-Undang RI Nomor 35 Tahun 2014 Tentang Perubahan Kedua Atas UU Nomor 23 Tahun 2002 Tentang Perlindungan Anak, (Bandung: Citra Umbara, 2016), 4. 
Hak lain yang melekat pada anak, termasuk kewajiban orang tua bagi anak juga termuat dalam undang-undang No. 35 tahun 2014 tentang perubahan atas undang-undang No. 23 Tahun 2002 Tentang Perlindungan Anak Pasal 4 menyebutkan bahwa: "Setiap anak berhak untuk dapat hidup, tumbuh, berkembang dan berpartisipasi secara wajar sesuai dengan harkat dan martabat kemanusiaan, serta mendapat perlindungan dari kekerasan dan diskriminasi".20

Kewajiban dan tanggung jawab orang tua dalam UndangUndang Nomor 35 Tahun 2014 Tentang Perubahan Atas Undang-Undang Nomor 23 Tahun 2002 Tentang Perlindungan Anak, bagian keempat pasal 26 yaitu:

1) Orang tua berkewajiban dan bertanggung jawab untuk:

a) Mengasuh, memelihara, mendidik, dan melindungi anak.

b) Menumbuh kembangkan anak sesuai dengan kemampuan, bakat, dan minatnya.

c) Mencegah terjadinya perkawinan pada usia anak-anak.

d) Memberikan pendidikan karakter dan penanaman nilai budi pekerti pada anak.

2) Dalam hal orang tua tidak ada, atau tidak diketahui keberadaannya, atau karena suatu sebab, tidak dapat melaksanakan kewajiban dan tanggung jawabnya, maka kewajiban dan tanggung jawab sebagaimana yang dimaksud dalam ayat (1) dapat beralih kepada keluarga, yang dilaksanakan sesuai dengan ketentuan peraturan perundangundangan yang berlaku.21

4. Dalam Garis Besar Haluan Negara (GBHN) Tahun 1998

Berdasarkan GBHN Tahun 1998, tanggung jawab pendidikan oleh kedua orang tua terhadap anak antara lain sebagai berikut:

a. Memelihara dan membesarkannya. Tanggung jawab ini merupakan dorongan alami untuk dilaksanakan, karena anak

20 Undang-Undang RI Nomor 35 Tahun 2014 Tentang Perubahan Kedua Atas UU Nomor 23 Tahun 2002 Tentang Perlindungan Anak, (Bandung: Citra Umbara, 2016), 6 .

21 Ibid., 63. 
memerlukan makan, minum, dan perawatan agar ia dapat hidup secara berkelanjutan.

b. Melindungi dan menjamin kesehatannya, baik secara jasmaniah maupun rohaniah dari berbagai gangguan penyakit atau bahaya lingkungan yang dapat membahayakan dirinya.

c. Mendidiknya dengan berbagai ilmu pengetahuan dan ketrampilan yang berguna bagi hidupnya, sehingga apabila ia telah dewasa ia mampu berdiri sendiri dan membantu orang lain serta melaksanakan kekhalifahannya.

d. Membahagiakan anak untuk dunia dan akhirat dengan memberikan pendidikan agama sesuai dengan ketentuan Allah sebagai tujuan hidup muslim.22

Orang tua mempunyai kewajiban besar untuk melindungi anak seperti yang telah ditetapkan pasal di atas. Tetapi dengan bergulirnya waktu banyak pula orang tua yang tidak bertanggung jawab dengan tugasnya sendiri. Disinilah tugas orang tua yang harus mengubah kebiasaan buruk dalam mengasuh anak menjadi orang tua yang bertanggung jawab dengan menjalankan kewajibannya sehingga generasi mendatang mempunyai kekuatan mental untuk menghadapi perubahan dalam masyarakat.

\section{Hak Anak}

1. Dalam Undang-undang No. 4 tahun 1979 tentang kesejahteraan anak

Sebagaimana dituangkan dalam undang-undang No. 4 tahun 1979 tentang kesejahteraan anak. Pasal 1 undang-undang tersebut menentukan: "kesejahteraan anak adalah tata kehidupan dan penghidupan anak yang dapat menjamin pertumbuhan dan perkembangannya dengan wajar, baik secara rohani, jasmani maupun sosial. Usaha kesejahteraan anak adalah usaha kesejahteraan sosial yang ditujukan untuk menjamin terwujudnya kesejahteraan anak terutama terpenuhinya kebutuhan pokok anak."

Pasal 2 undang-undang tersebut menyebutkan :

22 M. Yatimin Abdullah, Pengantar Studi Etika, (Jakarta: PT. Raja Grafindo), 2006, 104. 
a. Anak berhak atas kesejahteraaan, perawatan, asuhan dan bimbingan berdasarkan kasih sayang baik dalam keluarganya maupun didalam asuhan khusus untuk tumbuh kembang dengan wajar.

b. Anak berhak atas pelayanan untuk mengembangkan kemampuan dan kehidupan sosialnya, sesuai dengan kebudayaan dan kepribadian bangsa untuk menjadi warga negara yang baik dan berguna.

c. Anak berhak atas pemeliharaan dan perlindungan, baik semasa dalam kandungan maupun sesudah dilahirkan.

d. Anak berhak atas perlindungan terhadap lingkungan hidup yang dapat membahayakan atau menghambat pertumbuhan dan perkembangannya dengan wajar.

2. Dalam Kompilasi Hukum Islam (KHI)

Hak seorang anak adalah mendapatkan perawatan, pengobatan serta pendidikan, sebagaimana diatur dalam Pasal 80 ayat 4 yang berbunyi: "suami dengan penghasilannya, suami menanggung:

a. Nafkah, kiswah dan tempat kediaman bagi istri;

b. Biaya rumah tangga, biaya perawatan dan biaya pengobatan bagi istri dan anak;

c. Biaya pendidikan bagi anak.

Selanjutnya terkait dengan hak anak dijelaskan dalam Pasal 81 ayat 1, yakni: "suami wajib menyediakan tempat kediaman bagi istri dan anak-anaknya, atau bekas istri yang masih dalam masih masa iddah."

3. Dalam Undang-undang No. 35 tahun 2014 tentang perubahan atas undang-undang No. 23 Tahun 2002 Tentang Perlindungan Anak

Undang-undang No. 35 tahun 2014 tentang perubahan atas undang-undang No. 23 tahun 2002 tentang perlindungan anak, juga menjelaskan terkait hak-hak anak, sebagai berikut:

a. Pasal 8: "berhak memperoleh pelayanan kesehatan dan jaminan sosial sesuai dengan kebutuhan fisik, mental, spiritual dan sosial". 
b. Pasal 9: "berhak memperoleh pendidikan dan pengajaran dalam rangka pengembangan pribadinya dan tingkat kecerdasannya sesuai dengan minat dan bakatnya".

c. Pasal 11: "berhak untuk beristirahat dan memanfaatkan waktu luang, bergaul dengan anak sebaya, bermain, berekreasi dan berkreasi sesuai dengan minat bakat dan tingkat kecerdasannya demi pengembangan diri".

d. Pasal 13: "berhak mendapat perlindungan dari perlakuan diskriminasi dan eksploitasi, baik ekonomi maupun seksual, penelantaran, kekejaman, kekerasan, penganiyayaan, ketidakadilan dan perlakuan salah lainya".

e. Pasal 14: "berhak untuk diasuh oleh orang tuanya sendiri, kecuali jika ada alasan dan/atau aturan hukum yang sah menunjukkan bahwa pemisahan itu adalah demi kepentingan terbaik bagi anak dan merupakan pertimbangan terakhir".

Sedangkan berdasarkan konvensi hak-hak anak, hak-hak anak secara umum dapat dikelompokkkan dalam 4 kategori dalam pemenuhan hak dasar anak antara lain:

a. Hak hidup, meliputi: hak mendapatkan nama dan status kewarganegaraan, hak hidup bersama orang tuanya, kewajiban negara melindungi anak-anak dari segala bentuk salah perlakuan, hak perlindungan dari penyalahgunaan obat bius dan narkotika.

b. Hak tumbuh dan berkembang, meliputi: hak memperoleh informasi, hak memperoleh pendidikan, hak bermain dan rekreasi, hak untuk pengembangan kepribadian, hak memperoleh identitas, hak untuk di dengar, hak memperoleh pengembangan kesehatan dan fisik.

c. Hak berpartisipasi, meliputi: hak untuk menyatakan dan didengar pendapat, hak untuk mendapatkan, mencari dan memberikan informasi- informasi dan

d. Hak terhadap perlindungan, meliputi: adanya larangan diskriminasi anak dan larangan eksploitasi anak.23

\section{Gambaran Umum Tentang Era Digital.}

23 M. Nasir Djamil, Anak Bukan Untuk Dihukum Catatan Pembahasan UU Sistem Peradilan Pidana Anak (UU-SPPA), (Jakarta: Sinar Grafika, 2015), 14-16. 
McLuhan bersama Quentin Fiore menyatakan bahwa media pada setiap zamannya menjadi esensi masyarakat.24 McLuhan menyatakan bahwa media berfungsi sebagai kepanjangan indra manusia pada masing-masing era, yaitu sebagai berikut :

1. Era Kesukaan

Selama era kesukaan indra pendengaran, penciuman dan perasa merupakan indra yang lebih banyak digunakan manusia terlebih yang pertama. Pada periode ini, kebudayaan sangat berorientasi pada pendengaran dan orang berkomunikasi lebih mengandalkan telinga.

2. Era Tulisan

Pada era tulisan menekankan pada indra penglihatan yang ditandai dengan diperkenalkannya huruf abjad (alphabet) dan karenanya mata menjadi indra dominan dalam berkomunikasi.

3. Era Cetak

Penemuan mesin cetak memberikan tanda munculnya era cetak dalam peradaban manusia dan awal revolusi industri. Jika era tulisan memungkinkan orang lebih bergantung pada fungsi visual maka pada era cetak ketergantungan tersebut lebih meluas.

4. Era Elektronika

Era elektronika telah membawa manusia kembali pada situasi kesukaan yang lebih menekankan pada komunikasi secara lisan (oral). Media elektronik memiliki ciri sebagaimana percakapan lisan yang bersifat segera dan singkat yang berarti penerimaan informasi dan reaksi yang diberikan bersifat segera dan singkat. Menurut McLuhan, pada era elektronik orang berbicara melalui televisi, radio, kaset rekaman, gambar foto, mesin penjawab, telepon, blog dan e-mail.25

5. Era Digital

Dengan adanya perkembangan teknologi di bidang teknologi informasi juga memicu perubahan besar dalam

24 Marshall McLuhan dan Quentin Fiore, The Medium is the Massage, Bantam Books, New York 1967 dalam Richard West dan Lynn H. Turner, Introducing Communication Theory, 464.

25 Morisson, Teori Komunikasi Individu Hingga Massa, Jakarta: Kencana Prenamedia Group, 2013), 488-491. 
teknologi digitalisasi yakni semua konten media baik cetak dan elektronik dapat digabungkan dan didistribusikan. Flew mengemukakan media digital adalah bentuk dari konten media yang menggabung dan mengintegrasikan data, teks, suara dan beragai gambar yang tersimpan dalam format digital dan didistribusikan melalui suatu jaringan seperti kabel serat optic, satelit dan system transmisi gelombang rendah. Adapun di era digital manusia menggunakan media seperti internet.26

Secara garis besar bahwa perubahan dari era kesukaan hingga era digital mempengaruhi manusia dalam berinteraksi dan berkomunikasi menggunakan media. Dennis Mc Quail memberikan lima konsep pembeda antara lain :

1. Derajat Interaktivitas yaitu interaksi dalam era digital lebih fleksibel dan lebih tinggi disbanding era sebelumnya.

2. Derajat Social Presence, yaitu era sebelumnya media bersifat personal dan mengurangi ambiguitas, sedangkan era digital memungkinkan audience untuk bisa berhubungan secara personal dengan media melalui kontak langsung.

3. Derajat Otonomi, yaitu penggunaan media di era digital memiliki kemampuan untuk mengontrol isi dan penggunaan medianya sendiri dan menjadi sumber independen.

4. Derajat Playfullness, yaitu kemampuan media di era digital menyediakan hiburan bagi para user.

5. Derajat Privasi, yaitu manusia bebas menampilkan apapun di era digital sehingga menghasilkan media yang unik dan personal.27

Era digital dapat ditunjukkan dengan hadirnya media internet dan jejaring sosial. Sejak ditemukannya internet, telah terjadi perubahan besar dalam komunikasi massa. Media massa lama (surat kabar, radio, televisi) bukan lagi satu satunya sumber informasi. Kehadiran internet bagi pengguna merupakan sebuah media baru yang menawarkan keberagaman dan kebebasan akan akses informasi bagi pengguna tanpa harus terikat pembatasan dan sensor.

26 Apriadi Tamburaka. Literasi Media, (Jakarta: PT RajaGrafindo Persada, 2013), 72.

27 Ibid, 74. 
Teknologi di era digital masa kini yang semakin canggih menyebabkan terjadinya perubahan besar dunia. Manusia telah dimudahkan dalam melakukan akses terhadap informasi melalui berbagai cara serta dapat menikmati fasilitas dari teknologi digital dengan bebas, namun dampak negative muncul pula sebagai mengancam. Tindak kejahatan mudah terfasilitasi, game online dapat merusak mental generasi muda, pornografi dan pelanggaran hak cipta mudah dilakukan oleh setiap manusia jika tidak menggunakan media dengan baik di era digital.

\section{Dampak Era Digital Terhadap Anak.}

Kemajuan media informasi dan teknologi sudah diarasakan oleh lapisan masyarakat, baik dari segi positif maupun negatif dari penggunanya. Hal ini dikarenakan pengaksesan media informasi dan teknologi ini tergolong sangat mudah atau terjangkau untuk berbagai kalangan, baik untuk kawula muda maupun tua dan kalangan kaya maupun menengah ke bawah. Bahkan pada umumnya, saat ini anakanak usia 5 hingga 12 tahun menjadi pengguna paling banyak dalam memanfaatkan kemajuan media informasi dan teknologi pada saat ini. Oleh karena itu, tidak heran jika dampak positif dari perkembangan media informasi dan teknologi untuk anak usia 5 hingga 12 tahun dikatakan sebagai generasi multi-tasking.28

Seiring perkembangan zaman, pemikiran orang tua pada saat inipun sudah mengalami perbedaan yang tergolong jauh dengan pemikiran orang tua pada zaman terdahulu. Kemudian akses dalam mendapatkan gadget seperti tablet yang ada di era digital saat ini, membuat para orang tua modern tidak perlu lagi membelikan beraneka ragam mainan untuk anaknya. Cukup membelikan satu tablet dimana pada saat ini harganya semakin tergolong terjangkau oleh masyarakat luas, segala macam permainan sudah bisa didapatkan secara mudah jika dibandingkan dengan masa lalu yang penuh dengan permainan tradisional.29

28 Semiawan, Kenakalan Remaja dan Usaha-Usaha Pengatasannya dalam Kebidupan Keluarga, (Jakarta: Yayasan Obor Etlabora, 1994), 36.

29 Ery Soekresno, Menyiapkan Anak Tangguh di Era Digital, (Bandung: Asy-Syamil, 2011), 17. 
Keadaan seperti ini membuat anak semakin dimanjakan dengan kecanggihan gadget tersebut, dimana sekali klik dapat mengakses beraneka ragam permainan dan informasi yang teraktual pada saat ini. Ketika diumpakan seperti dua sisi uang logam, gadget ini memiliki dampak positif dan juga dampak negatif untuk perkembangan anak. Dampak positif dari penggunaan dari media infomasi dan teknologi ini adalah antara lain untuk mempermudah seorang anak dalam mengasah kreatifitas dan kecerdasan anak. Adanya beragam aplikasi digital seperti mewarnai, belajar membaca dan menulis huruf tentunya memberikan dampak positif bagi perkembangan otak anak.

Anak tidak memerlukan waktu dan tenaga yang lebih untuk belajar membaca dan menulis di buku atau kertas, cukup menggunakan tablet sebagai sarana belajar yang tergolong lebih menyenangkan. Anak-anak menjadi lebih bersemangat untuk belajar karena aplikasi semacam ini biasanya dilengkapi dengan animasi yang menarik, warna yang cerah, serta lagu-lagu yang ceria. Selain itu, kemampuan berimajinasi anak juga semakin terasah karena permainan yang mereka gunakan bervariasi dan memiliki jalan cerita yang beragam. 30

Namun kemudahan akses konten internet ini pula yang akan menyebabkan anak memperoleh apa yang belum saatnya diperoleh, baik berupa gambar, tulisan, suara dan lain sebagainya. Di berbagai media pemberitaan seperti koran dan televisi, telah ditemukan berbagai berita mengenai anak di bawah umur yang mengakses situs porno.

Selain hal yang telah disebutkan di atas, jejaring sosial juga berdampak pada anak dan remaja di masa sekarang, yaitu anak terlalu cepat merasa puas dengan pengetahuan yang didapatkan dari dunia internet, padahal pada umumnya berbagai informasi dari interet sebagian besar hanya berisikan sebuah kesimpulan.

Selain itu, kemajuan teknologi berdampak pada kurangnya sosialisasi anak kepada teman-temannya karena lebih menyukai menyendiri dan permainan teknologi. Kemajuan teknologi memiliki potensi mendorong anak untuk menjalin hubungan yang lemah.

30 Ery Soekresno, Menyeimbangkan Waktu Layar dan Waktu Sebari-Hari, (Bandung: Asy-Syamil, 2011), 22. 
Waktu yang seharusnya digunakan untuk bercengkrama secara langsung berkurang karena waktu tersebut tersita hanya untuk menikmati semuanya dalam kesendirian. Bahkan permainan pun bersifat individual, sehingga menyebabkan semakin kecil lingkup jalinan hubungan yang luas. Keadaan seperti ini dapat memberikan dampak negatif terhadap pernikahan dan hubungan kerja anak tersebut di masa yang akan datang.

Kemungkinan terbesar yang akan terjadi adalah anak tersebut akan terbiasa menjalin huungan tidak langsung dengan individual lain, melainkan bergantung pada biro jasa online, sehingga dapat menyebabkan anak tersebut mengalami kesulitan untuk ke dalam hubunan yang lebih mendalam.31

Kebutuhan teknologi yang bertanggung jawab, mutlak diperlukan untuk mengimbangi melemahnya kontrol sosial dalam masyarakat di zaman digital yang penuh dengan turbulensi, kekacauan dan serbuan teknolgi yang sulit dibendung sebagai dapak globalisasi, harus cerdas untuk memilih penggunaan teknologi buat mereka sendiri begitu juga dengan anak-anak dan pernah remaja.

Keterbukaan terhadap perkembangan teknologi tidak semuanya buruk. Hasil penelitian pada video game dan bebarapa media elektronik lainnya dapat meningkatkan kemampuan anak dalam memecahkan masalah, reaksi terhadap rancangan meningkatkan kemampuan anak dalam menyimak sesuatu. Di sisi lain, penggunaan mesin pencari di internet membuat anak mengalami penurunan kemampuan dalam mengingat dan menemukan sesuatu.

\section{Tanggung Jawab Orang Tua Kepada Anak di Era Digital.}

Sangat disayangkan kemajuan teknologi informasi dan komunikasi saat ini mempengaruhi gaya hidup (lifestyle) manusia di semua lini kehidupan, baik dari anak-anak hingga orang dewasa. Derasnya arus globalisasi telah merubah pola dan cara pikir manusia saat berkomunikasi. Hal inilah yang terkadang menjadi kendala bagi tiap-tiap anggota keluarga, khususnya interaksi orang tua dengan anak mereka. Perbedaan generasi orang tua dengan anak diyakini menjadi salah satu pengaruh betapa sulitnya menjalin komunikasi

31 Ibid., 20-22. 
dengan anak mereka. Menurut Don Tapscopt dalam bukunya Grown Up Digital, anak-anak yang lahir di tahun 2000an telah mahir dalam menggunakan teknologi seperti internet, media sosial, smartphone, dan gadget tanpa mengetahui sejarah perkembangan teknologi tersebut.32

Teknologi informasi dan komunikasi dalam media digital telah membangkitkan banyak konteks baru untuk anak-anak untuk mengekspresikan dan menjelajahi identitas mereka, dari situs jaringan sosial, telepon seluler, dan platform untuk blog dan vlogs, dunia maya, dan situs berbagi video instant messaging.

Menurut Davis dalam jurnalnya yang berjudul Young People's Digital Lives: The Impact Of Interpersonal Relationships and Digital Media Use On Adolescents' Sense of Identity, bahwa teknologi digital media seperti telepon selular dan situs jejaring sosial telah menciptakan konteks sosial baru dalam kasus yang telah ada perubahannya. Salah satunya hubungan interpersonal orang tua dan anak (baik anak usia dini maupun remaja) mengalami perbedaan dalam konteks sosial.33

Dalam Teori Ekologi Media atau seringkali disebut sebagai Teori Determinasi Teknologi yang disampaikan McLuhan yang diambil dari jurnal Komunikasi dalam Era Teknologi karya Erni Herawati, mengasumsikan bahwa teknologi media telah menciptakan revolusi di tengah masyarakat karena masyarakat sudah sangat tergantung kepada teknologi dan tatanan masyarakat terbentuk berdasarkan pada kemampuan masyarakat menggunakan teknologi. Artinya, masyarakat dunia tidak mampu menjauhkan dirinya dari pengaruh teknologi, McLuhan juga menyatakan bahwa teknologi tetap akan menjadi pusat bagi semua bidang profesi dan kehidupan. Pendapat tersebut sesuai dengan apa yang dikemukakannya, we shape our tools and they in turn shape us, pada dasarnya teknologi yang kita buat secara tidak langsung telah membentuk kita, terutama dalam hal berkomunikasi. Teknologi informasi dan komunikasi di era digital telah menjadi penyebab utama perubahan. Menurut Griffin, mencatat pendapat McLuhan

32 Don Tapscott, Grown Up Digital: Yang Muda yang Mengubah Dunia. (Jakarta: PT. Gramedia Pustaka, 1997), 40.

33 S. B. Djamarah, Pola Komunikasi Orang Tua dan Anak dalam Keluarga (Perspektif Pendidikan Islam). (Jakarta: Renika Cipta, 2004), 23. 
yang dikutip dari jurnal Komunikasi dalam Era Teknologi karya Erni Herawati, bahwa media elektronik baru telah secara radikal mengubah cara manusia berpikir, merasa, dan bertindak. 34

Hadirnya beragam jenis teknologi informasi dan komunikasi membuat anak-anak menjadi konsumen aktif dimana teknologi saat ini tidak hanya hadir dalam satu bentuk melainkan bermacammacam seperti smartphone, tablet, notebook, hingga televisi.

Dalam penggunaan smartphone anak-anak cukup konsumtif ketimbang notebook ataupun televisi. Rata-rata setiap harinya anakanak menghabiskan waktu 5 jam untuk bermain smartphone. Telepon pintar ini memang menawarkan kecanggihan yang membuat anakanak ketagihan dalam menggunakannya. Mereka dapat mengunakannya untuk berkomunikasi, mengirim pesan, mencari hiburan dengan bermain games hingga melakukan aktifitas online.

Kegiatan yang anak-anak lakukan tersebut berkaitan dengan apa yang Don Tapscott kemukakan. Don Tapscott mengatakan bahwa anak-anak era digital saat ini multitasking. Mengerjakan lima hal dalam waktu yang bersamaan: mulai dari mengirim pesan, ngetwit download musik, upload video, nonton film di youtube, dan melihat apa yang temannya sedang kerjakan di facebook. Selain itu anak mengenal teknologi dipengaruhi oleh keluarga terutama orang tuanya yang memfasilitasi dengan alasan mau tidak mau memang menyesuaikan dengan kebutuhan anaknya. Pengaruh juga datang dari teman-teman sebayanya atau teman sepermainannya. 35

Hal ini berbanding terbalik dengan akses orang tuanya sebagai orang yang memfasilitasi mereka akan perangkat digital tersebut. Hal ini juga dapat dilihat dari bagaimana orang tua menggunakan teknologi informasi dan komunikasi berdasarkan kebutuhan mereka saja. Misalnya untuk bekerja, untuk memperlancar bisnis, hingga sebagai kebutuhan komunikasi dan gaya hidup saat ini. Meskipun begitu, orang tua harus paham akan dampak-dampak yang ditimbulkan dari penggunaan gadget yang berlebihan.

34 Erni Herawati, Komunikasi dalam Era Teknologi Komunikasi dan Informasi. Jurnal Humaniora, Vol. 2, No.1, April 2011: 100-109.

35 Don Tapscott, Grown Up Digital: Yang Muda yang Mengubah Dunia, (Jakarta: PT. Gramedia Pustaka, 1997), 64. 
Jika orang tua yang mengajarkan hal yang tepat dalam penggunaan media digital, maka media digital itu tersebut juga akan membawa dampak-dampak positif untuk orang tua dan anak, seperti media pendekatan untuk belajar bersama. Namun jika orang tua hanya sekedar memberikan fasilitas tersebut dengan mengesampingkan efek-efek negatif yang timbul, maka anak akan terbawa dampak negatifnya seperti berperilaku anti sosial, acuh terhadap lingkungan sekitarnya, dan yang paling parah kecanduan akan pornografi, seks, dan kekerasan.

Berdasarkan hal di atas, perlunya orang tua menimbang kembali alasan mereka dalam memberikan fasilitas media digital tersebut untuk anak. Orang tua juga perlu tahu seberapa pentingkah media digital untuk anak usia dini. Alasan untuk berkomunikasi dan memenuhi kebutuhan anak di era digital ini menjadi alasan kuat bagi setiap orang tua memberikan perangkat digital untuk anak-anaknya.

\section{Tanggung Jawab Orang Tua Kepada Anak Di Era Digital Perspektif Hukum Keluarga Islam di Indonesia.}

Agama Islam menjelaskan terkait dengan tanggung jawab seseorang dalam berkehidupan sehari-hari, sebagaimana dalam surat al-Mudatstsir ayat 38:36

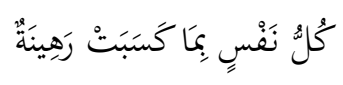

Tiap-tiap diri bertanggung jawab atas apa yang telah diperbuatnya.

Dalam Islam, keluarga adalah sebuah tatanan fitrah yang Allah tetapkan bagi jenis manusia. Bahkan para Rasul dan Nabi Allah pun menjalani hidup berkeluarga. Hal itu membuktikan bahwa keluarga adalah sebuah institusi suci, mengandung hikmah dan memiliki misi ilahiah secara abadi.

Perjalanan keluarga selanjutnya mengharuskan orang tua untuk bertanggung jawab, bahkan mengharuskan orang tua menyelengggarakan sosialisasi, memberikan arah pendidikan, pengisian jiwa yang baik dan bimbinngan kejiwaan. karena anak adalah anugerah dan amanah dari Allah SWT yang harus di pertanggung jawabkan oleh setiap orang tua dalam berbagai aspek kehidupannya.

36 Depaterment Agama, al-Qur'an (Bandung: CV. Penerbit Diponegoro, 2006), 576. 
Allah SWT memperingatakan kepada setiap Orang tua sebagai pemegang peranan yang penting dan amat berpengaruh anakanaknya untuk dijaga dengan baik sebagaimana dalam surah AtTahrim ayat 6 , sebagai berikut: 37

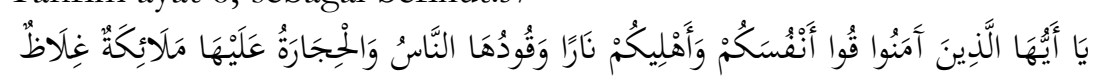

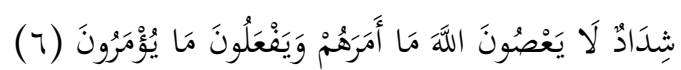

Orang-orang yang beriman, peliharalah dirimu dan keluargamu dari api neraka yang bahan bakarnya adalah manusia dan batu; penjaganya malaikatmalaikat yang kasar, yang keras, yang tidak mendurbakai Allah terhadap apa yang diperintabkan-Nya kepada mereka dan selalu mengerjakan apa yang diperintabkan.

Islam menyadari pentingnya pemenuhan hak-hak dasar anak demi kepribadian anak. Sebagaimana hak anak adalah bagian dari hak asasi manusia yang harus dijamin, dilindungi dan dipenuhi baik oleh orang tua, keluarga, masyarakat, pemerintah dan negara. Untuk itu anak membutuhkan perlindungan, perlindungan anak bertujuan untuk menjamin terpenuhinya hak-hak anak agar dapat hidup, tumbuh, berkembang, dan berpartisipasi secara optimal sesuai dengan harkat dan martabat kemanusiaan. Diantaranya hak-hak anak adalah sebagai berikut :

1. Mendapatkan asuhan dan pemeliharaan,

2. Kepemilikan harta benda,

3. Memperoleh pendidikan dan pengajaran,

4. Mendapatkan perawatan dan perlakuan sosial.

Selain itu, kewajiban orang tua bagi anak juga termuat dalam undang-undang No. 35 tahun 2014 tentang perubahan atas undangundang No. 23 Tahun 2002 Tentang Perlindungan Anak Pasal 4 menyebutkan bahwa: "Setiap anak berhak untuk dapat hidup, tumbuh, berkembang dan berpartisipasi secara wajar sesuai dengan harkat dan martabat kemanusiaan, serta mendapat perlindungan dari kekerasan dan diskriminasi".

Berdasarkan hal-hal tersebut di atas, peran dan tanggung jawab orang tua menjadi kunci kesuksesan dalam mendidik dan merawat anak-anaknya di era digital ini. Orang tua hendaknya lebih

37 Ibid., 
melindung, mengawasi dan memberikan perhatian kepada anak secara lebih aktif dan langkah-langkahnya sebagai berikut seperti yang diungkapkan Elly Risman dalam seminar yang berjudul "peran Ayah di era digtal" :

1. Kenali kondisi, kebutuhan dan sikap anak,

2. Memperbaiki komunikasi antara orang tua dan anak,

3. Bijak dalam berteknologi,

4. Mengantar anak sampai pernikahannya.

Islam telah mengatur tanggung jawab orang tua kepada anak, yang mana tetap relevan diterapkan di era digital saat ini. Adapun tanggung jawab tersebut dapat diklasifikasikan sebagai berikut:

1. Memelihara dan membesarkannya (bifdzul 'ird). Tanggung jawab ini merupakan dorongan alami untuk dilaksanakan, karena anak memerlukan makan, minum dan perawatan, agar ia dapat hidup secara berkelanjutan. Tanggung jawab ini masih harus dipegang oleh orang tua di era digital, yang mana memelihara dan membesarkan disini harus dimaknai bahwa orang tua perlu memperhatikan hal-hal apa saja yang dilakukan anak di era digital yakni seperti apa saja yang diakses anak melalui gadgetnya, perlunya memberikan pelajaran terkait dengan perkembangan ilmu teknologi dan membentengi mereka terhadap konten negatif yang ditimbulkan oleh perkembangan teknologi tersebut.

2. Melindungi dan menjamin kesehatannya, baik secara jasmaniah maupun rohaniah dari berbagai gangguan penyakit atau bahaya lingkungan yang dapat membahayakan dirinya (bifdzun nafs). Tanggung jawab ini juga harus senantiasa dipegang orang tua terhadap anak-anaknya, yang mana tidak dapat dipungkuri di era digital saat ini banyak anak yang tak bisa lepas dari gadgetnya, padahal bila hal ini dilakukan secara terus menerus dapat merusak dan menciderai kesehatan anak. Dengan begitu hal ini merupakan tanggung jawab yang tak boleh dilupakan oleh orang tua.

3. Mendidiknya dengan berbagai ilmu pengetahuan dan ketrampilan yang berguna bagi hidupnya, sehingga apabila ia telah dewasa, ia mampu berdiri sendiri dan membantu orang lain (bifdzul aq). Demikianpun dengan tanggung jawab ini, orang tua tidak boleh menutup anak dengan melarang ia mengenal 
perkembangan ilmu pengetahuan di era digital saat ini. Padahal dengan mengenal perkembangannya dapat mengasah perkembangan berfikir dan kreatifitasnya. Dengan begitu, orang tua tetap bertanggung jawab mendidik anaknya sesuai dengan berbagai ilmu pengetahuan dan keterampilan di era digital saat ini, namun juga harus memperhatikan dan memfilter mana yang diperlukan demi perkembangan si anak.

4. Membahagiakan anak untuk dunia akhirat dengan memberinya pendidikan agama sesuai dengan ketentuan Allah sebagai tujuan akhir hidup muslim (bifdzud dien). Kesadaran akan tanggung jawab mendidik dan membina anak secara terus menerus perlu dikembangkan kepada setiap orang tua, mereka juga perlu dibekali teori-teori pendidikan modern sesuai dengan perkembangan zaman. Tanggung jawab ini merupakan aspek terpenting dalam mendidik anak di era digital, bahwa anak dibolehkan mengikuti perkembangan ilmu pengetahuan dan teknologi saat ini, namun orang tua wajib untuk memberikan pendidikan agama sesuai dengan ketentuan agama. Apalah arti hebat dan mumpuni dalam berbagai ilmu teknologi bilamana ilmu agama terlupakan begitu saja.

\section{Penutup}

Dari beberapa penjelasan yang peneliti paparkan pada bab-bab sebelumnya, ada dua kesimpulan penting yang menjadi poin inti dalam kajian yang ditulis di sini, yaitu :

1. Perkembangan dunia informasi dan teknologi di era digital yang sangat pesat, sehingga berdampak pada perkembangan anak, baik itu semakin bagus atau terpuruk. Hal ini, mengaharuskan orang tua dalam tanggung jawabnya kepada anak untuk lebih selektif dalam memberikan gadget pada anak dan meningkatkan komunikasi antara orang tua dengan anak serta memahami sifat atau karakter anak.

2. Perspektif hukum keluarga Islam di Indonesia terhadap tanggung jawab orang tua di era digital saat ini masih relevan untuk diterapkan. Mengingat dalam Islam melindungi anak merupakan amanah Allah kepada setiap orang tua untuk selalu dipenuhi hakhaknya, diantaranya : pemeliharaan atas kehormatan (hifz al-ird, ), pemeliharaan atas hak beragama (hifź al-din), pemeliharaan atas 
Nur Ahmad Yasin: Tanggung Jawab Orang Tua Kepada Anak......

jiwa (hifz al-nafs), pemeliharaan atas akal (hifz al-'aql), pemeliharaan atas harta (hiff $\mathbf{z}$ al-māh).

\section{Daftar Pustaka}

Abdul Rahman Ghozali. Fiqh Munakahat, Jakarta: Kencana, 2008.

Abdurrahman. Kompilasi Hukum Islam di Indonesia, Jakarta: Akademika Pressindo, 2007.

Abū 'Abdillah Muḥammad ibn Ismā̄il ibn Ibrāhīm bin Mughīrah bin Bardizbah al-Bukhāri. Șahīh al-Bukhāri Juz I, Riyadh: Dār al-Salam, 2008.

Aditya panji, "Hasil Survei Pemakaian Internet Remaja Indonesia", https://tekno.kompas.com/read/2014/02/19/1623250/

Hasil.Survei.Pemakaian.Internet.Remaja.Indonesia, “ 28 maret 2018".

Apriadi Tamburaka. Literasi Media, Jakarta: PT RajaGrafindo Persada, 2013.

Don Tapscott. Grown Up Digital: Yang Muda yang Mengubah Dunia, Jakarta: PT. Gramedia Pustaka, 1997.

Erni Herawati, Komunikasi dalam Era Teknologi Komunikasi dan Informasi. Jurnal Humaniora, Vol. 2, No.1, April 2011.

Ery Soekresno, Menyiapkan Anak Tangguh di Era Digital, Bandung: Asy-Syamil, 2011.

M. Nasir Djamil. Anak Bukan Untuk. Dibukum Catatan Pembahasan UU Sistem Peradilan Pidana Anak (UU-SPPA), Jakarta: Sinar Grafika, 2015.

M. Yatimin Abdullah. Pengantar Studi Etika, Jakarta: PT. Raja Grafindo, 2006.

Mahmudah. Keluarga Muslim, Surabaya: PT. Bina Offset, 1994.

Marshall McLuhan dan Quentin Fiore, 'The Medium is the

Massage', dalam Richard West dan Lynn H. Turner, Introducing Communication Theory, Bantam Books, New York 1967.

Morisson, Teori Komunikasi Individu Hingga Massa, (Jakarta: Kencana Prenamedia Group, 2013.

Muchsin, Menggagas Etika Dan Moral Di Tengah Modernitas, Surabaya: CV. Adis, 2002. 
Mufidah. Psikologi Keluarga Islam Berwawasan Gender, Malang: UINMalang Press, 2008.

Rifa Hidayah. Psikologi Pengasuban Anak, Malang: UIN-Malang Press, 2009.

Rita pranawati. "menjadi orang tua di era digital", https://ritapranawati.id/2018/03/20/menjadi-orangtuadi-era-digital//, "28 maret 2018".

S. B. Djamarah. Pola Komunikasi Orang Tua dan Anak dalam Keluarga (Perspektif Pendidikan Islam), Jakarta: Renika Cipta, 2004.

Semiawan. Kenakalan Remaja dan Usaba-Usaba Pengatasannya dalam Kehidupan Keluarga, Jakarta: Yayasan Obor Etlabora, 1994.

Burgerlijk Wetboek. Kitab Undang-undang Hukum Perdata, Terj. Soesilo dan Pramudji, Rhedbook Publisher, 2008.

Departemen Agama. Al-Qur'an dan Terjemabnya, Bandung: CV. Penerbit J-ART, 2006.

Departemen Pendidikan Nasional. Kamus Besar Bahasa Indonesia, edisi 3, Jakarta: Balai Pustaka: 2007.

KPAI. "era digital jaman now membuat para ibu harap cemas", http://www.kpai.go.id/berita/era-digital-jaman-nowmembuat-para-ibu-harap-harap-cemas/ "28 maret 2018".

Undang-Undang No. 35 tahun 2014 perubahan atas UndangUndang No. 23 tahun 2002 tentang Perlindungan Anak. 